\title{
Editorial
}

\section{Safe and Valuable Endoscopy in the COVID Era}

\author{
Diogo Libânio ${ }^{a, b}$ Pedro Bastos ${ }^{a}$ Pedro Pimentel-Nunes ${ }^{a-c}$ \\ ${ }^{a}$ Gastroenterology Department, Instituto Português de Oncologia do Porto, Porto, Portugal; ${ }^{b}$ MEDCIDS - \\ Department of Community Medicine, Health Information and Decision, Faculty of Medicine, University of Porto, \\ Porto, Portugal; ' 'Surgery and Physiology Department, Faculty of Medicine, University of Porto, Porto, Portugal
}

\section{Keywords \\ COVID · Coronavirus · Endoscopy · Gastroenterology · Safety}

\section{Endoscopia segura e efetiva em tempos de COVID}

\section{Palavras Chave}

COVID · Coronavirus · Endoscopia · Gastrenterologia ·

Segurança

The entire world is facing a new challenge due to the COVID-19 outbreak that led to a disruption in habits, behaviours, perceptions of risk/benefits, and health priorities. Besides the multiple questions caused by these times of uncertainty, questions about endoscopy practice also emerged and without simple answers: how can we protect ourselves, our co-workers, our patients and our families? What procedures should we keep, and which ones should we defer?

Evidence-based medicine could not answer most of endoscopists' questions, and thus Committees and Societies made an effort to provide some answers, supported by scarce evidence, but mostly based on expert consensus. Since several guidelines now exist, it is useful to summarize and compare the answers to these questions.

\section{KARGER}

(C) 2020 Sociedade Portuguesa de Gastrenterologia Published by S. Karger AG, Basel

Karger

Upen access

This article is licensed under the Creative Commons AttributionNonCommercial-NoDerivatives 4.0 International License (CC BYNC-ND) (http://www.karger.com/Services/OpenAccessLicense). Usage and distribution for commercial purposes as well as any distribution of modified material requires written permission.

\section{Valuable Endoscopy - What Should We Do Now and What Defer?}

Most of the guidelines (as well as the Portuguese Health Directory) recommend postponing elective, nonurgent/non-essential procedures. The rationale for this includes minimizing risks to other patients and staff, the probable declining of staff availability along the outbreak, and rational use of protective personal equipment (PPE), consumables and devices, as supply chains are placed under stress.

However, since the temporal frame of this outbreak is unclear, there are situations in which diagnostic or therapeutic endoscopy is not urgent but should not be deferred indefinitely since it may impact prognosis. The answer to the question - what we should keep and what we should defer (and to when) - is not simple but imagining the probability of a change in prognosis if the procedure is delayed by 1-3 months can help us decide.

Table 1 summarizes the recommendations of the American Society of Gastrointestinal Endoscopy (ASGE) and British Society of Gastrointestinal Endoscopy (BSG) $[1,2]$. In summary, both guidelines recommend perform-

D.L. and P.B. contributed equally in the writing of the article.

Diogo Libânio

Department of Gastroenterology, IPO-Porto

Rua Dr. António Bernardino de Almeida

PT-4200-072 Porto (Portugal)

diogolibaniomonteiro@gmail.com 
Table 1. Summary of ASGE and BSG recommendations on priority of endoscopic procedures

\begin{tabular}{|c|c|c|}
\hline & ASGE & BSG \\
\hline \multicolumn{3}{|l|}{ GI bleeding } \\
\hline Upper GI bleeding & Do not delay & \\
\hline Lower GI bleeding & Do not delay & Do not delay if ongoing \\
\hline Iron deficiency anaemia & Case-by-case & NA \\
\hline Obliteration of varices (secondary prevention) & \multicolumn{2}{|c|}{ Case-by-case } \\
\hline Food impaction / foreign bodies & \multicolumn{2}{|c|}{ Do not delay } \\
\hline \multicolumn{3}{|l|}{ Symptoms } \\
\hline Non-alarm symptoms & \multicolumn{2}{|l|}{ Delay } \\
\hline Alarm symptoms & Not addressed & Case-by-case $^{1}$ \\
\hline Dysphagia & \multicolumn{2}{|c|}{ If significantly impacts oral intake, do not delay } \\
\hline \multicolumn{3}{|l|}{ Screening/surveillance } \\
\hline Screening / surveillance EGD & Delay & - \\
\hline Screening / surveillance colonoscopy & Delay & - \\
\hline Positive FIT or fecal DNA & Delay 4-6 weeks and reassess & Delay \\
\hline Surveillance/treatment of premalignant or malignant lesions & Do not delay & In detail below \\
\hline Low-risk follow-up (esophagitis / ulcer healing) & NA - see above & Delay \\
\hline Surveillance of Barrett's/varices & NA - see above & Delay \\
\hline Submucosal lesions, pancreatic cysts non-high risk & NA & Delay EUS \\
\hline IBD (general) & Do not delay if impacts management & Adressed below in detail \\
\hline New suspected acute colitis & & Case-by-case ${ }^{2}$ \\
\hline Disease assessment & Do not delay if impacts management & Delay \\
\hline \multicolumn{3}{|l|}{ Therapeutic procedures / others } \\
\hline Planned EMR/ESD for high-risk lesions & NA - see above & $\begin{array}{l}\text { Case-by-case, if deemed } \\
\text { essential }\end{array}$ \\
\hline Nutrition support (urgent inpatient PEG/NJ tube) & NA & Do not delay \\
\hline Therapy of perforations/leaks (including vacuum therapy) & NA & Do not delay \\
\hline Palliation of GI obstruction (includes biliary) & \multicolumn{2}{|c|}{ Do not delay } \\
\hline Cholangitis & \multicolumn{2}{|c|}{ Do not delay ERCP } \\
\hline Symptomatic pancreaticobiliary disease & \multicolumn{2}{|c|}{ Do not delay drainage } \\
\hline \multicolumn{3}{|l|}{ Elective therapeutic procedures (stricture dilation, APC for GAVE, } \\
\hline RFA, POEM, pneumatic dilation, ampullectomy) & NA & Delay \\
\hline EUS for cancer staging / treatment planning & Do not delay & $\begin{array}{l}\text { Case-by-case (if signifi- } \\
\text { cantly impacts therapy } \\
\text { planning) }\end{array}$ \\
\hline
\end{tabular}

GI, gastrointestinal; NA, not addressed; ASGE, American Society of Gastrointestinal Endoscopy; BSG, British Society of Gastroenterology. ${ }^{1}$ BSG recommends 2-week wait / urgent suspected cancer referrals should be submitted to triage by a group of consultants, reserving endoscopic procedures for those judged to be at highest risk. ${ }^{2}$ Perform endoscopy if infection excluded and symptoms not settling after empirical treatment.

ing emergent/urgent endoscopy (acute gastrointestinal bleeding, foreign bodies/food impaction and cholangitis), as well as some therapeutic procedures (palliation of obstruction, nutritional support, closure of leaks/perforation, biliary drainage). Investigation of patients with non-alarm symptoms, and most screening or surveillance procedures should generally be deferred (including patients with positive FIT/faecal DNA). Patients with cancer should be staged if this impacts on treatment plan- ning, and EMR/ESD as well as investigation of alarm symptoms should be decided on a case-by-case basis, bearing in mind that the yield of cancer detection even in patients with classical alarm symptoms is somewhat low. The known long natural history of colonic polyps should also be balanced with the risks of polypectomy/EMR/ESD and the reduced but existing risk of severe adverse events that requires intensive care treatment. 
The European Society of Gastrointestinal Endoscopy (ESGE) has not yet produced detailed recommendations about specific procedures but advises to postpone endoscopy if the procedure is elective (non-urgent/emergent) and the risk of COVID-19 morbimortality is higher than the risk of gastrointestinal disease morbimortality [3]. The Portuguese Society of Digestive Endoscopy (SPED) recommends deferring procedures not considered essential until community transmission is controlled but no specific recommendation is made according to the indication [4]. It should also be noted that decisions should take into account not only these general recommendations but also resource availability, level of community infectivity and risk to the patient.

\section{Safety - How Should We Protect Ourselves and Our Patients?}

Firstly, postponing elective procedures decreases travel needs and crowding in hospitals, and also reduces workload (and thus transmission risk at the time of endoscopy) and use of resources (both PPE and human resources).

Secondly, health care professionals in endoscopy rooms are at a higher risk of infection due to inhalation of airborne droplets, conjunctival contact, touch contamination and viral material in faeces $[5,6]$. All endoscopic procedures, but particularly EGD, are aerosol-generating procedures.

In order to avoid or mitigate these risks, strict adherence to a correct PPE praxis should be implemented in endoscopy units [7]. Additionally, the physical structure of the endoscopy unit may need to be adapted, in order to separate infected patients from healthy ones. In general, this Journal endorses the recommendations recently published by SPED [4]. Care should be taken when reading national guidelines since they are drafted with a particular territory in mind and should be adapted to different scenarios taking into account the available resources and the pandemic phase. In fact, the dynamics of the epidemiological curve changes very quickly, influencing the population and individual infection risk. Another factor that will likely be a game changer is the availability of point-of-care tests to detect the SARS-CoV-2 virus and the serological tests.

At the present time, Portugal is in the so-called "mitigation" phase in which community viral spread occurs and it appears to be reaching the peak or plateau of new cases. In these circumstances, we consider that there are no low-risk endoscopic procedures and the following assumptions are based on this premise.

If an endoscopic procedure is scheduled, a two-tier screening scheme should be followed: the first level is a telephone call to confirm the procedure and question about COVID-19 symptoms; the second level is a clinical and epidemiological questionnaire made before the admission to the institution or endoscopy department. Some countries also measure body temperature and in Wuhan, the epicentre of the pandemic, a chest CT was used as a screening test [8]. If a patient is suspected of being infected, the procedure should be postponed and local orientation guidelines followed. When admitted to the endoscopy unit, the patient is given a surgical mask and hand gloves. If the latter is not possible, meticulous hand hygiene is mandatory. Every health care worker (HCW) that contacts a patient should wear appropriate PPE, which varies according to the level of exposure and the patient infection status (Table 2). Organizational measures to diminish the personnel number present in the endoscopy unit and, most importantly, in the endoscopy suite are strongly suggested. So is the constitution of teams that remain together during the entire day or even week, in order to minimize staff exposure [9].

After the exam, particular caution in doffing the PPE is to be taken and room and scope disinfection is done accordingly to best practice methodology.

Extra care is advised when dealing with suspected or positive COVID patients, with full PPE provided to all staff that are in contact with the patient and endoscopic procedures performed in a negative pressure room, if available. This last statement lacks solid supportive evidence and is based on the viability of SARS-CoV-2 in aerosol [10] and airflow dynamics modelling studies from the SARS-CoV-1 and MERS-CoV outbreaks [11]. If a negative pressure room is not available, proper venting is of paramount importance and the room should not be used again until after $1-3 \mathrm{~h}$.

Due to the possibility that infected individuals may be asymptomatic in the early stages of the disease, but they already demonstrate infectious potential, we suggest contacting all patients submitted to endoscopy 1-2 weeks after the procedure.

\section{What Next?}

Realistically, it is unlikely that the virus will disappear by itself or that group immunity is going to be achieved soon. Moreover, probably not before 1 year a 
Table 2. Recommendations of PPE according to level of exposure

\begin{tabular}{|c|c|c|}
\hline \multicolumn{2}{|l|}{ Setting } & \multirow{2}{*}{$\begin{array}{l}\text { PPE suggested }{ }^{\mathrm{a}} \\
\text { Surgical mask }\end{array}$} \\
\hline $\begin{array}{l}\text { HCW not in contact with } \\
\text { patients }\end{array}$ & $\begin{array}{l}\text { - Administrative } \\
\text { personnel } \\
\text { - Others }\end{array}$ & \\
\hline $\begin{array}{l}\text { HCW in contact with } \\
\text { patients outside endoscopy } \\
\text { room }\end{array}$ & $\begin{array}{l}\text { - Admitting nurse } \\
\text { - Recovery room } \\
\text { personnel }\end{array}$ & $\begin{array}{l}\text { Hairnet } \\
\text { Surgical mask } \\
\text { Eye protection (face shield or goggles) } \\
\text { Gloves } \\
\text { Long-sleeve gown } \\
\text { Clogs }\end{array}$ \\
\hline $\begin{array}{l}\text { HCW in the endoscopy } \\
\text { room of COVID-free } \\
\text { patients }\end{array}$ & $\begin{array}{l}\text { - Endoscopy MD } \\
\text { - Endoscopy nurse } \\
\text { - Anaesthesia team }{ }^{\mathrm{c}}\end{array}$ & $\begin{array}{l}\text { Hairnet } \\
\text { Respirator mask (FFP2) } \\
\text { Eye protection (face shield preferred) } \\
\text { Double pair of gloves } \\
\text { Long-sleeve fluid-resistant gown or gown plus apron } \\
\text { Clogs with protection }\end{array}$ \\
\hline $\begin{array}{l}\text { HCW in the endoscopy } \\
\text { room of suspected or } \\
\text { confirmed COVID patients } \\
\text { (if possible in a negative } \\
\text { pressure room) }\end{array}$ & $\begin{array}{l}\text { - Endoscopy MD } \\
\text { - Endoscopy nurse } \\
\text { - Anaesthesia team }\end{array}$ & $\begin{array}{l}\text { High profile hairnet } \\
\text { Respirator mask (FFP3/2) } \\
\text { Face shield } \\
\text { Double pair of gloves } \\
\text { Long-sleeve fluid resistant gown } \\
\text { Clogs with leg protection }\end{array}$ \\
\hline
\end{tabular}

HCW, health care worker; FFP, filtering face piece. ${ }^{\text {a }}$ Proper training of donning and doffing PPE should be provided. ${ }^{\mathrm{b}}$ We support the recommendations of the WHO and CDC regarding extended use of these equipment. Reutilization of face masks and respirators is not advisable. ${ }^{c}$ Only elements present in the room during OT intubation, if this is required.

vaccine will be available for the general population. For how long can we keep all these restrictions to endoscopy without compromising the care of our patients? As soon as the infection transmission in the population is controlled and the government eases the restrictions to people mobility it is our opinion that also the indications for endoscopy should be reviewed. We have to remember that endoscopy plays a major role in our patients' health and that endoscopic screening methods and treatments have shown to improve survival. Gradually we should consider non-urgent indications for performing selective endoscopies, including screening and surveillance procedures at a later stage. However, health personnel and patients' protection measures will never be the same and this will probably be a good thing and a major improvement in endoscopy practice. In fact, whenever possible, the safety measures outside the critical phase should probably be the same as the ones in the critical one. Some exceptions might be considered depending on the patient and HCW COVID-19 status (previously infected and confirmed cured may not deserve such strict safety measures) and on the endoscopic procedure being performed (the colonoscopy infection transmission risk is predictably much lower than EGD and a surgical mask instead of a FFP2 could be an option when resources are limited). Of course, this is going to be a dynamic process and we should follow the different society recommendations through time. Nevertheless, we should keep in mind that not doing endoscopy for several months implies that in the future some patients will die not from COVID but because of the COVID restrictions and, in our opinion, this cannot be an option!

\section{Conclusion}

As stated above, HCWs have an increased risk of contracting COVID-19 and dramatic cases of deaths amongst health personnel are reported daily by the media. This has 
led to multiple emotional and felt manifestations of pride and support by the community, often characterizing HCWs as brave "warriors" or combatants. Even though courage is needed to face these difficult times, caution and judicious use of resources are fundamental so that endoscopists can help fight the pandemic. This Journal supports all the endoscopists that struggle in their units to provide the best possible care to patients at the same time that they take all the precautions not to get infected. There are several ways gastroenterologists can help stop the COVID-19 pandemic; as endoscopists we believe that the best way to help is to practice a safe and valuable endoscopy.

\section{Disclosure Statement}

The authors declare no conflicts of interest of any king regarding the manuscript.

Funding Sources

None.

\section{Author Contributions}

Diogo Libânio, Pedro Bastos and Pedro Pimentel-Nunes participated in the conception, writing and revision of the manuscript. The final version was approved by the authors.

\section{References}

1 Gastroenterology Professional Society Guidance on Endoscopic Procedures during the Covid-19 Pandemic [cited 2020 Apr 6]. Available from: https://www.asge.org/home/advanced-education-training/covid-19-asgeupdates-for-members/gastroenterology-professional-society-guidance-on-endoscopicprocedures-during-the-covid-19-pandemic.

2 Endoscopy activity and COVID-19. BSG and JAG guidance - update [cited $2020 \mathrm{Apr} 3$ ]. Available from: https://www.bsg.org.uk/covid-19-advice/endoscopy-activity-and-covid19-bsg-and-jag-guidance/?utm_source= Members\&utm_campaign $=\mathrm{ffd} 002 \mathrm{~b} 62 \mathrm{~b}$ EMAIL_CAMPAIGN 2020_02_13_03_21 COPY_01\&utm_medium=email\&utm term $=0$ be 5 fefa $54 d-f f d 002 b 62 b-\& m c$ cid=ffd002b62b\&mc_eid=\%5bUNIQID\%5d.

3 ESGE and ESGENA Position Statement on gastrointestinal endoscopy and the COVID-19 pandemic. Available from: https:// www.esge.com/esge-and-esgena-positionstatement-on-gastrointestinal-endoscopyand-the-covid-19-pandemic/.
4 COVID-19 e endoscopia digestiva $-3^{\circ}$ comunicado. Available from: https://www.sped.pt/ images/2020/Covid-19/SPED_e_COVIDcomunicado_3.pdf.

5 Gu J, Han B, Wang J. COVID-19: Gastrointestinal Manifestations and Potential FecalOral Transmission. Gastroenterology. 2020 Mar;S0016-5085(20)30281-X.

6 Huang C, Wang Y, Li X, Ren L, Zhao J, Hu Y, et al. Clinical features of patients infected with 2019 novel coronavirus in Wuhan, China. Lancet. 2020 Feb;395(10223):497-506.

7 Direção Geral de Saúde - Colocação e remoção de EPI em procedimentos invasivos das vias respiratórias. Available from: https:// www.youtube.com/watch?v=Cetbrfw77rg.
8 Castro Filho EC, Castro R, Fernandes FF, Pereira G, Perazzo H. Gastrointestinal endoscopy during COVID-19 pandemic: an updated review of guidelines and statements from international and national societies. Gastrointest Endosc. 2020 Apr;S0016-5107(20) 34132-8.

9 Sultan S, Lim JK, Altayar O, Davitkov P, Feuerstein JD, Siddique SM, et al.; AGA. AGA Institute Rapid Recommendations for Gastrointestinal Procedures During the COVID-19 Pandemic. Gastroenterology. 2020 Mar;S0016-5085(20)30458-3.

10 van Doremalen N, Bushmaker T, Morris DH, Holbrook MG, Gamble A, Williamson BN, et al. Aerosol and Surface Stability of SARSCoV-2 as Compared with SARS-CoV-1. N Engl J Med. 2020 Apr;382(16):1564-7.

11 Yu IT, Li Y, Wong TW, Tam W, Chan AT, Lee $\mathrm{JH}$, et al. Evidence of airborne transmission of the severe acute respiratory syndrome virus. N Engl J Med. 2004 Apr;350(17):1731-9. 